\title{
Evaluation of Bio-Accumulation Stress in Chicken by Arsenite: A Haematological Case Study
}

\author{
Luqman Rasul $^{* 1}$, Shahid Tufail ${ }^{2}$ and Hassan Rasool ${ }^{2}$ \\ ${ }^{*}$ Department of Chemistry, Minhaj University, Lahore, Pakistan. \\ ${ }^{2}$ Department of Zoology, Government Postgraduate College for Boys Gojra, Pakistan. \\ *Corresponding Author Email: rasool719@gmail.com \\ Received 17 June 2016, Revised 19 September 2016, Accepted 19 September 2016
}

\begin{abstract}
Broiler is consumed by human population in large quantities. Its brooding conditions are very important due to their linkage with the financial impacts involved in poultry industry. These brooding conditions are not only vital due to economic reasons but also extremely important due to health impacts on chickens and human population being terminal consumers. As (III) presence in the drinking water is resulted in bio-accumulation in chicks being brooded under otherwise similar conditions except drinking water. This bio-accumulation disturbs the eco-physiological and blood parameters. Haematological studies of anti-coagulated and serum blood samples core parameters reveals that As (III) contamination in drinking water is the significant source of adverse disturbance of blood parameters of red blood cell, white blood cell, hemoglobin, packed cell volume, sodium, calcium, potassium ions, albumin, urea, creatinine and cholesterol, with a highly significant $\mathrm{p}$ value of less than 0.01 after $14^{\text {th }}$ brooding day with bio-accumulation of 25.8 $\mu \mathrm{g} / \mathrm{L}$ of As (III) in blood samples.
\end{abstract}

Keywords: As (III), Broiler, Bio-accumulation, Haematology, Stress.

\section{Introduction}

Metals are a potent source of environmental contamination. Due to persistent nature of metals, they can accumulate in organisms particularly that are long lived, high in the food chain or live in industrial areas exposed to anthropogenic sources $[1,2]$. Some metals can bio accumulates up food chain with the passage of time. Thus, greater concentration is found in higher tropic level organisms [3, 4]. Arsenic (As) is one of such metals that causes bio-accumulation and is poisonous in nature [5]. Broiler was used as a study material since it is a vital dietary part of human population. A person consumes $12 \mathrm{~kg}$ of this bird as a protein source annually [6]. The second determining factor selected for study was As contaminated drinking water. Arsenic contaminated water has played a chaotic part in many countries including Pakistan [7]. Water contains As in inorganic form as oxyanions of arsenite (As III) or arsenate (As V) [8].
Among other pollution issues As pollution is also a major concern in Pakistan [9] especially for fresh water reservoirs of the country. According to National Standards for Drinking Water Quality [10] permissible limit for As in drinking water is $50 \mu \mathrm{gL}^{-1}$ while it is $10 \mu \mathrm{gL}^{-1}$ as per EPA and WHO $[11,12]$. Normally fresh water contains As in the range of $1-10 \mu \mathrm{gL}^{-1}$ and this concentration is reached up to level of $100-5000 \mu \mathrm{gL}^{-1}$ in regions of sulfide mineralization and mining [13]. Major water reservoirs of Pakistan have elevated As contamination like Tarbela $\left(620 \mu \mathrm{gL}^{-1}\right)$, Chashma (750 $\left.\mathrm{gL}^{-1}\right)$, and Lloyd $\left(620 \mu \mathrm{gL}^{-1}\right)$. Moreover; ground water sample from different cities of Pakistan have shown concentration of $80 \mathrm{\mu gL}^{-1}$ [14].

Absorption rate of inorganic As is better than organic As. It can be absorbed in gastrointestinal tract or respiratory tract [15]. After 
absorption, 93-99\% of As binds with the globin of hemoglobin in red blood cells and is distributed within whole body with in a day. After absorption, it can persist in different body parts like hair, nail and skin [15].

Bioaccumulation of As can disturb the eco-physiological parameters [16, 17, 18]. Freshly hatched one day old chicks brooding under controlled conditions of $32^{\circ} \mathrm{C}$ with $30-50 \%$ relative humidity (RH) in the litter at placement have shown adverse effects in body weight $(\mathrm{g})$, feed consumption $(\mathrm{g})$, feed conversion $(\mathrm{g} / \mathrm{g})$, mortality rate (numbers) and core internal body temperature $\left({ }^{\circ} \mathrm{C}\right)$. Decreased body weight, decreased feed consumption, slow feed conversion, high mortality rate and lowered core internal body temperature are found correlated with the elevated levels of As (III) in the blood samples of chicken in our previous study [19].

In this present study, hematological studies of anti-coagulated and serum blood samples core parameters are done. This study leads to the conclusion that As (III) bioaccumulates in these different parts of chicken. This bioaccumulated As can further produce deleterious health effects on human beings.

\section{Material and Methods Blood sampling}

$2 \mathrm{ml}$ of blood was collected from the jugular vein of the chickens purchased from a hatchery of equal male and female ratio after first, seventh and fourteenth brooding day time span at 11:00 hr day time. Two flocks of chickens were designed for this study and each flock was having hundred chickens. First flock considered as standard and was given mineral water purchased from market with mineral contents $\left(\mathrm{mgL}^{-1}\right)$ in following concentrations; Calcium (40-70), Magnesium (4-15), Sodium (7-30), Potassium (0.02-0.10), Fluoride (0.2-0.05), Chloride (77-150) and Sulphate (12-50). The second flock considered as tested birds was treated with As (III) spiked ground water, collected from river catchment areas. The elevated level of As (III) $>10 \mathrm{mgL}^{-1}$ in contaminated drinking water may cause its toxicological impacts as reported elsewhere [20].
$0.5 \mathrm{ml}$ of each $2 \mathrm{ml}$ blood sample was separated and taken into clean bijou bottles having anticoagulant solution. Remaining $1.5 \mathrm{ml}$ of each sample was left for clotting at room temperature for 3 hours and then at $4{ }^{\circ} \mathrm{C}$ for overnight. Blood in bijou bottles was used for red blood cell (RBC), white blood cell (WBC), hemoglobin ( $\mathrm{Hb})$ and packed cell volume (PCV). Serum from blood was collected from clotted blood after centrifugation at $2000 \mathrm{rpm}$ for $10 \mathrm{~min}$ at room temperature. Serum was stored at $20^{\circ} \mathrm{C}$ till the performance of tests in the sterile plastic tubes.

\section{Brooding conditions}

One day old chicken of $37 \pm 2(\mathrm{~g})$ weight were given brooding conditions of $32^{\circ} \mathrm{C}$ [21] with controlled relative humidity of $\geq 50 \%$ for a time span of 14 days. Two 100 Watt bulb were used permanently as light source. PS-500-020 digital thermo hygrometer by OMEGA was used for monitoring relative humidity. Two flocks were brooded simultaneously and were given same feed purchased from market. One flock was given mineral water for drinking and second flock was given As (III) contaminated drinking water.

\section{Hemotological study}

Anticoagulated blood samples and serum samples were used for examining parameters. Hemocytometer method was used for counting RBC's and WBC's. Cyanmethemoglobin method was used for measuring $\mathrm{Hb}$ level. Microhematocrit method was applied for determining PCV which is percentage of RBC in blood. Serum salts were found using flame photometry [22]. As (III) bioaccumulation was done by the method used in our previous study using differential pulse anodic stripping voltammetric technique [19]. Urea and creatinine were checked using SMA 12/60 analyzer following standard Technicon method [22]. Cholesterol level was checked by Cole method [23].

\section{Statistical analysis}

Mean of all the observed values taken after $1^{\text {st }}, 7^{\text {th }}$ and $14^{\text {th }}$ brooding day were calculated for both the anti-coagulated and serum blood samples 
for the two flocks. Standard deviations were also calculated to apply unpaired test to find out $\mathrm{p}$ value. p-value is helpful to determine whether As (III) contaminated drinking water impacts were significant or not as compared to the normal mineral drinking water. If the two-tailed p-value is found to be near 0.0001 then this difference is known to be extremely statistically significant [22].

\section{Results and Discussion Anti-coagulated blood sample analysis}

As has viable potential of bioaccumulation [24, 25]. Analysis of As (III) bioaccumulation in our recent study revealed adverse effects on the health conditions of birds since it results in decreased body weight, decreased feed consumption, decreased feed conversion, higher mortality rate and lowered core internal body temperature within first 14 days of brooding period [19]. Similar effects were reported in literature when brooding chicks were given heavy metals contaminated water $[26,27,28]$. The tested birds of flock 2 were under bio-accumulation stress of $25.8 \mu \mathrm{gL}^{-1}$ after $14^{\text {th }}$ day of brooding (Fig. 1). Anticoagulated blood sample analysis captured RBC, count WBC, concentration $\mathrm{Hb}$ and PCV as core parameters. The hematological parameters like count $\mathrm{RBC}, \mathrm{WBC}$, count concentration $\mathrm{Hb}$ and PCV of anti-coagulated blood sample analysis were found adversely effected in flock 2 gradually shown in Table 1 on the basis of statistical significance of two-tailed $\mathrm{p}$ values calculated by the application of unpaired $t$-test.

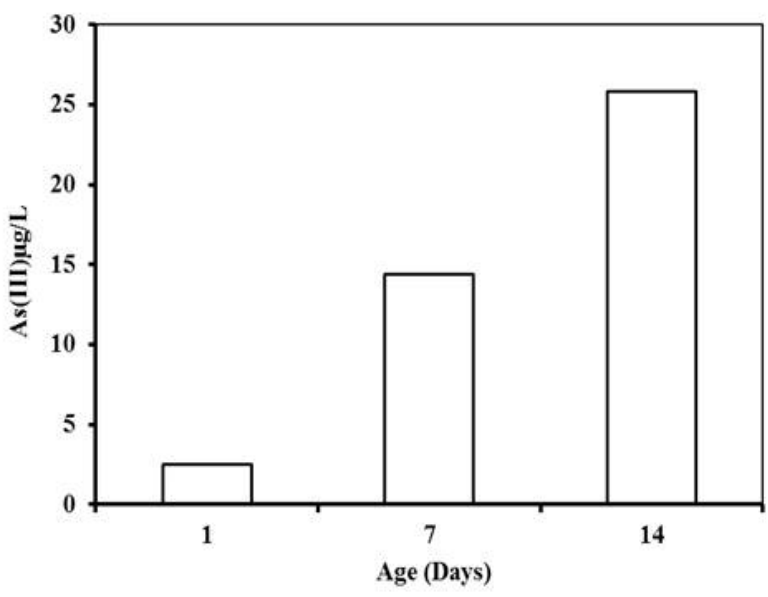

Figure 1. Trend of As (III) bio-accumulation by poultry birds at flock 2

The resulted data of $p$ values for $R B C$, WBC, $\mathrm{Hb}$ and PCV after 14th brooding day found as $0.0005,0.0010,0.0107$ and 0.0004 respectively. However, after $1^{\text {st }}$ brooding day, $\mathrm{p}$ values between the two flocks were found in the range of 0.17-0.81 and $\mathrm{p}$ significance was low. While, after $7^{\text {th }}$ and $14^{\text {th }}$ brooding days, $p$ value was found in the range of 0.016-0.04 and 0.0004-0.0107 respectively. Thus, after $7^{\text {th }}$ and $14^{\text {th }}$ brooding day $\mathrm{p}$ values were found to be significantly high ( $\mathrm{p}<0.001)$. This suggests that As (III) contaminated drinking water is highly significant in the administration of adverse effects.

Table 1. The variation in the level of clinical parameters of anti-coagulated blood samples of controlled and tested poultry birds of two flocks.

\begin{tabular}{|c|c|c|c|c|c|c|c|}
\hline & & ameters & & $\begin{array}{c}\text { RBC } \\
\left(10^{3} / \mathrm{L}\right)\end{array}$ & $\begin{array}{c}\text { WBC } \\
\left(10^{9} / \mathrm{L}\right)\end{array}$ & $\mathrm{Hb}\left(\mathrm{mgdL}^{-1}\right)$ & PCV (\%) \\
\hline \multirow{3}{*}{$\begin{array}{l}\text { After } 1^{\text {st }} \\
\text { brooding day }\end{array}$} & Flock 1 & Controlled Birds & Mean \pm SD & $2.50 \pm 0.45$ & $23.1 \pm 1.53$ & $11.1 \pm 0.11$ & $32.8 \pm 0.86$ \\
\hline & Flock 2 & Tested Birds & Mean \pm SD & $2.38 \pm 0.69$ & $24.8 \pm 1.03$ & $11.0 \pm 0.38$ & $33.2 \pm 1.02$ \\
\hline & & $p$-value ( $t$-test) & & 0.81 & 0.17 & 0.65 & 0.62 \\
\hline \multirow{3}{*}{$\begin{array}{l}\text { After } 7^{\text {th }} \\
\text { brooding day }\end{array}$} & Flock 1 & Controlled Birds & Mean \pm SD & $2.52 \pm 0.19$ & $23.0 \pm 0.93$ & $26.0 \pm 1.06$ & 32.90 .92 \\
\hline & Flock 2 & Tested Birds & Mean \pm SD & $2.03 \pm 0.21$ & $11.2 \pm 0.09$ & $10.9 \pm 0.11$ & $30.1 \pm 0.79$ \\
\hline & & $p$-value ( $t$-test) & & 0.040 & 0.022 & 0.027 & 0.016 \\
\hline \multirow{3}{*}{$\begin{array}{l}\text { After } 14^{\text {th }} \\
\text { brooding day }\end{array}$} & Flock 1 & Controlled Birds & Mean \pm SD & $2.52 \pm 0.19$ & $23.0 \pm 0.93$ & $11.2 \pm 0.09$ & $32.9 \pm 0.92$ \\
\hline & Flock 2 & Tested Birds & Mean \pm SD & $2.03 \pm 0.21$ & $26.0 \pm 1.06$ & $10.9 \pm 0.11$ & $30.1 \pm 0.79$ \\
\hline & & $p$-value ( $t$-test) & & 0.040 & 0.022 & 0.027 & 0.016 \\
\hline
\end{tabular}




\section{Serum blood sample analysis}

Serum salts and other core parameters were studied in previous studies to evaluate the stress factors [22]. Serum blood parameters such as $\mathrm{Na}^{+}, \mathrm{K}^{+}, \mathrm{Ca}^{2+}$, albumin, urea, creatinine and cholesterol were checked for the two flocks and unpaired $t$-test was applied.. The resulted data revealed that the studied serum blood parameters of two flocks were found in the range of 0.57-0.86 (Table 2). These finding reflected that there is no significant difference between two flocks. Whereas, this $\mathrm{p}$ value was found in the range of $0.020-0.049$ and $0.0001-0.0178$, after $7^{\text {th }}$ and $14^{\text {th }}$ brooding day, respectively. Statistically, this was evaluated that As(III) bioaccumulates in the serum blood samples. Thus, this study revealed that the bioaccumulation of As(III) was increased with respect to period of consumption of $\mathrm{As}(\mathrm{III})$ contaminated drinking water by poultry birds. Data of Table 2 suggests that As (III) contaminated drinking water is the significant factor that disturbed the serum blood core parameters. Heavy metals are toxic, non-degradable, and bioaccumulates in food chain and hence causes adverse effects [29]. This is also comparable to our previous study where As (III) bio-accumulation stress under same brooding conditions resulted in decreased body weight, decreased feed consumption, decreased feed conversion, higher mortality rate and lowered core internal body temperature [19].

Table 2. The variation in the level of clinical and biochemical parameters of serum samples of controlled and tested poultry birds of two flocks.

\begin{tabular}{|c|c|c|c|c|c|c|c|c|c|c|}
\hline \multicolumn{4}{|c|}{ Parameters } & $\begin{array}{c}\mathrm{Na}^{+} \\
\left(\mathrm{molL}^{-1}\right)\end{array}$ & $\begin{array}{c}\mathbf{K}^{+} \\
\left(\mathbf{m o l L}^{-1}\right)\end{array}$ & $\begin{array}{c}\mathrm{Ca}^{2+} \\
\left(\mathrm{molL}^{-1}\right)\end{array}$ & $\begin{array}{l}\text { Albumin } \\
\left(\mathrm{mgdL}^{-1}\right)\end{array}$ & $\begin{array}{c}\text { Urea } \\
\left(\mathrm{mgdL}^{-1}\right)\end{array}$ & $\begin{array}{c}\text { Creatinine } \\
\left(\mathrm{mgdL}^{-1}\right)\end{array}$ & $\begin{array}{l}\text { Cholesterol } \\
\left(\mathrm{mgdL}^{-1}\right)\end{array}$ \\
\hline \multirow{3}{*}{$\begin{array}{l}\text { After } 1^{\text {st }} \\
\text { brooding } \\
\text { day }\end{array}$} & Flock 1 & $\begin{array}{l}\text { Controlled } \\
\text { Birds }\end{array}$ & Mean \pm SD & $137 \pm 2.46$ & $4.20 \pm 0.51$ & $8.40 \pm 0.86$ & $2.79 \pm 0.28$ & $22.6 \pm 1.25$ & $0.94 \pm 0.23$ & $116 \pm 3.70$ \\
\hline & Flock 2 & Tested Birds & Mean \pm SD & $137 \pm 2.79$ & $4.3 \pm 0.67$ & $8.70 \pm 0.34$ & $2.93 \pm 0.42$ & $23.7 \pm 2.80$ & $0.98 \pm 0.30$ & 1145.90 \\
\hline & & $p$-value $(t$-tes & & 0.78 & 0.85 & 0.60 & 0.66 & 0.57 & 0.86 & 0.57 \\
\hline \multirow{3}{*}{$\begin{array}{l}\text { After } 7^{\text {th }} \\
\text { brooding } \\
\text { day }\end{array}$} & Flock 1 & $\begin{array}{l}\text { Controlled } \\
\text { Birds }\end{array}$ & Mean \pm SD & $134 \pm 3.60$ & $4.30 \pm 0.26$ & $8.60 \pm 0.49$ & 2.890 .15 & $21.7 \pm 1.39$ & $0.90 \pm 0.11$ & $112 \pm 2.90$ \\
\hline & Flock 2 & Tested Birds & Mean \pm SD & $143 \pm 1.60$ & $4.80 \pm 0.17$ & $7.40 \pm 0.34$ & $3.41 \pm 0.28$ & $24.8 \pm 1.17$ & $1.14 \pm 0.09$ & $120 \pm 4.00$ \\
\hline & & $p$-value of $(t$-te & & 0.020 & 0.049 & 0.025 & 0.047 & 0.041 & 0.043 & 0.049 \\
\hline \multirow{3}{*}{$\begin{array}{l}\text { After } 14^{\text {th }} \\
\text { brooding } \\
\text { day }\end{array}$} & Flock 1 & $\begin{array}{l}\text { Controlled } \\
\text { Birds }\end{array}$ & Mean \pm SD & $136 \pm 2.12$ & $4.00 \pm 0.18$ & $8.60 \pm 0.34$ & 2.850 .16 & $23.7 \pm 0.99$ & $0.90 \pm 0.13$ & $115 \pm 1.75$ \\
\hline & Flock 2 & Tested Birds & Mean \pm SD & $164 \pm 2.50$ & $3.20 \pm 0.22$ & $6.80 \pm 0.23$ & $4.23 \pm 0.17$ & $28.9 \pm 0.82$ & $1.27 \pm 0.10$ & $127 \pm 3.37$ \\
\hline & \multicolumn{3}{|c|}{$p$-value of ( $t$-test) } & 0.0001 & 0.0078 & 0.0016 & 0.0005 & 0.0022 & 0.0174 & 0.0053 \\
\hline
\end{tabular}

\section{Conclusion}

Hematological studies of chicken under bio-accumulation stress of As (III) in drinking water during the 14 days brooding period shows adverse impacts on anti-coagulated blood parameters; RBC, WBC, $\mathrm{Hb}$ and PCV and serum blood parameters; $\mathrm{Na}^{+}, \mathrm{K}^{+}, \mathrm{Ca}^{2+}$, albumin, urea, creatinine and Cholesterol. Bio-accumulation of $25.8 \mu \mathrm{gL}^{-1}$ in the blood samples after 14 days of brooding suggests that all adverse impacts are due to $\mathrm{As}$ (III) contamination in drinking water. Overall, this study suggests that drinking water should be checked for chickens as it impacts on the yield and quality of production in chicken.

\section{References}

1. S. W. Fowler, Mar. Environ. Res., 29 (1990) 1.https://doi.org/10.1016/01411136(90)90027-L

2. J. Burger, Environ. Research, 90 (2002) 33. https://doi.org/10.1006/enrs.2002.4381

3. R. Bargagli, R. Monaci, J. C. SanchezHernandez and D. Cateni, Mar. Eco. Prog. Ser., 169 (1998) 65. https://doi.org/10.3354/meps 169065

4. R. Scheifler, M. Gauthier-Clerc, C. L. Bohec, N. Crine, M. Coeurdassier and P. M. Badot, Environ. Toxicol. Chem., 24 (2005) 125. https://doi.org/10.1897/03-446.1 
5. K. A. Graeme and C. V. Pollack Jr, J. Emergen. Med., 16 (1998) 45.

6. M. Pattison, Poultry Diseases (Elsevier Limited, China) 6/e (2005).

7. J. Brinkel, M. H. Khan and A. Kraemer, Int. J. Environ. Res. Public Health, 6 (2009) 1609. https://doi.org/10.3390/ijerph6051609

8. P.L. Smedley, W.M. Edmunds and K. B. Pelig-Ba, In: Environmental Geochemistry and Health: with special reference to developing countries. (J. D. Appleton, R. Fuge and G. J. H. McCall,Eds) Geological Society Special Publication, London (1996) 163-181.

9. M. Ashraf, J. Tariq and M. Jaffar, Fish Res., 12 (1991) 355. https://doi.org/10.1016/01657836(91)90018-B

10. Pak-EPA, Pakistan Environmental Protection Agency, Ministry of Environment, Government of Pakistan (2008).

11. U.S. Environmental Protection Agency, Fed. Reg., 40 (1975) 990.

12. World Health Organization, Arsenic Compounds, Environmental Health Criteria ( Geneva, Switzerland) 2/e (2001) 224.

13. P. L. Smedley and D. G. Kinniburgh, Appl. Geochem., 17 (2002) 517. https://doi.org/10.1016/S08832927(02)00018-5

14. A. Rahman, H. K. Lee and M. A. Khan, Environ. Monit. Assess., 44 (1997) 339. https://doi.org/10.1023/A:1005747732104

15. D. J. Thomas, M. Styblo, and S. Lin, Toxicol. Appl. Pharma., 17 (2001) 127. https://doi.org/10.1006/taap.2001.9258

16. J.A. Baig, T.G. Kazi, A. Q. Shah, M. B. Arain, S. Khan, H. I. Afridi, G. A. Kandhro, N. F. Kolachi, Anal. Chim. Acta, 651 (2009) 57. https://doi.org/10.1016/j.aca.2009.07.065

17. A.Q. Shah, T. G. Kazi, M. B. Arain, J. B. Baig, H. I. Afridi, G. A. Kandhro, S. Khan, M. K. Jamali, J. Hazard. Mater., 167 (2009) 511. https://doi.org/10.1016/j.jhazmat.2009.01.03 1
18. A.Q. Shah, T.G. Kazi, J. A. Baig, H. I. Afridi, G.A. Kandhro, M. B. Arain, S. K. Wadhwa, N.F. Kolachi, Food Chem., 119 (2010) 840. https://doi.org/10.1016/j.foodchem.2009.08.0 41

19. L. Rasul, S. Tufail and H. Rasool, Asian J. Chem., 28 (2015) 1424.

20. J. K. Vodela, S. D. Lenz, J. A. Renden, W. H. Mcelhenney and B. W. Kemppainen, Poultry Sci., 76 (1997) 1493. https://doi.org/10.1093/ps/76.11.1493

21. R. Muchacka and E. Herbut, In: Proceedings of 13th International Congress in Animal Hygiene (Tartu, Estonia) volume 1 (2007) 337.

22. L. A. Durotoye, M. O. Fadairo and A. K. Avwemorue, Afr. J. Biomed. Res., 3 (2000) 143.

23. E. H. Coles, Veterinary Clinical Pathology (W.B. Saunders Company, Philadelphia, USA) (1986).

24. L. P. Ridgway and D. A. Karnofsky, Ann. N.Y. Acad. Sci., 55 (1952) 203. https://doi.org/10.1111/j.17496632.1952.tb26536.x

25. M. Athar, and S. B. Vohora, Heavy Metals and Environment (New Age International $(\mathrm{P})$ Limited Publishers, India) (1995).

26. F. W. Edens and J. D. Garlich, Poultry Sci., 62 (1983) 1757. https://doi.org/10.3382/ps.0621757

27. R. I. Bakalli, I. G. Pesti and W. L. Ragland, Vet. Hum. Toxicol., 37 (1995) 17.

28. P. R. Henry and M. D. Miles, Cienc. Anim. Bras., 2 (2001) 11.

29. N. Saha and M. R. Zaman, Environ. Monit. Assess., 185 (2013) 3867. https://doi.org/10.1007/s10661-012-2835-2 